\title{
ERRATA IN EARLY CHINA 6
}

The following corrections have been called to our attention. The editors ask our readers to call other errors and omissions to our attention so that future lists may be as complete as possible.

Page 36, right, line 42: For 116 B.C., read 104 B.C.

Page 57, right, line 6 of Chinese text: For 至于商, read 至接于分

Page 81, note 8, 1ine 1: For Chou-ylu, read Chou-yllan

Page 86, left, line 14: For Plastro-scapulomancy, read Plastro-scapulimancy

Page 87, right, line 9: For $天$, read 五

Page 93, left, line 40: For the missing graph, supply 今 